\title{
Weber e o Advento do Novo
}

\section{Renan Springer de Freitas}

Professor de Sociologia na Universidade Federal de Minas Gerais (UFMG).

E-mail: <springer@netuno.lcc.ufmg.br>

\section{INTRODUÇÃO}

D istinguir o velho do novo e mostrar como se transita de um para outro são, sabidamente, desafios que sempre moveram o pensamento sociológico, mas, no caso específico do pensamento weberiano, esses desafios adquiriram uma centralidade sem paralelo. Com efeito, o antagonismo entre o velho e o novo é um tema tão fundamental nos escritos de Weber que, sob a influência desses escritos, somos tentados a percebê-lo até mesmo nas mais inusitadas situações da vida cotidiana. Para me fazer entender, vou me permitir relatar dois episódios pitorescos, ocorridos há quase vinte anos, em Amsterdã, onde tive a oportunidade de morar quando jovem.

Certa vez, ao retornar de uma padaria, encontrei-me casualmente com a proprietária - uma holandesa que contava em torno de 60 anos - do pequeno edifício em que eu residia e pusemo-nos a conversar. Durante a conversa, uma moedinha (que me havia sido dada como troco na padaria) escapou-me das mãos e rolou pelo chão. Entretido que estava com o colóquio, não fiz menção de recuperar a moeda, o que me valeu uma pronta repreensão: "Você é rico, mas não jogue dinheiro fora", disse ela. Confesso que desconheço as razões que levaram-na a me supor tão abastado. Seja como for, alguns meses mais tarde, por motivos de que já não me lembro, essa senhora voltou a mencionar, mais uma

DADOS - Revista de Ciências Sociais, Rio de Janeiro, vol. 53, n-2, 2010, pp. 337 a 365. 
vez sem a menor cerimônia, minha suposta condição de "homem rico". Dessa vez, entretanto, resolvi reagir. Perguntei-lhe, em tom de brincadeira, se não queria trocar todos os bens que possuía por todos os que eu porventura possuísse. Ela então retrucou que eu voltasse a fazer a mesma proposta quando tivesse 60 anos.

Ao leitor de Weber não escapará que esses casos encerram um nítido confronto entre o velho e o novo. Assim, no que se refere ao primeiro episódio, dificilmente há algo de novo em desdenhar uma moeda perdida. No entanto, o fato de tal desdém se tornar objeto de uma repreensão moral como a que recebi é, na perspectiva weberiana, uma inequívoca novidade. Semelhantemente, o curto e bizarro diálogo que mantive com minha então senhoria, no segundo episódio, encerra claramente um confronto entre uma velha e uma nova concepção de enriquecimento. Desse modo, não há nenhuma novidade em conceber o enriquecimento, à minha maneira, como um feliz resultado de algumas poucas apostas bem-sucedidas, mas aprendemos com Weber que concebê-lo, de acordo com a visão de minha ex-senhoria, como um subproduto de anos a fio de uma vida regrada e dedicada ao trabalho é algo que indubitavelmente traz a marca do novo.

Uma vez caracterizadas as concepções em confronto, uma nova tarefa se impõe: explicar a transição de uma à outra. Em outras palavras, identificado o fosso que separa minha perspectiva da de minha exsenhoria, cumpre explicar o que teria provocado seu aparecimento. Com a ajuda de Weber, diríamos que isso está relacionado com o protestantismo em sua versão ascética, calvinista e, sobretudo, com o sectarismo que se lhe tornou peculiar. Afinal, Weber jamais se cansou de mencionar que a disciplina mental e moral demandada pelo sectarismo protestante - o qual, diga-se de passagem, deitou raízes na Holanda de uma forma como nada semelhante ocorreu no Brasil - é algo que jamais se viu em parte alguma antes de seu advento. Para ser mais preciso, Weber acreditava que o sectarismo protestante havia realizado um feito que nenhuma visão de mundo anterior ao advento da Reforma, nem mesmo o humanismo peculiar ao Renascimento, havia sido capaz de realizar: uma verdadeira "transformação da alma do homem" (Weber, 2003:368). Nessa perspectiva, poder-se-ia dizer que o protestantismo ascético forjou algo como um novo tipo de homem, do qual minha ex-senhoria holandesa, na medida em que, diferentemente de mim, concebia o enriquecimento como um subproduto de uma vida frugal e inteiramente dedicada ao trabalho, seria um claro exemplo. 
Há certamente quem conteste essa visão weberiana. O historiador Trevor-Roper, por exemplo, argumenta que nada há de particularmente protestante ou calvinista na disciplina mental e moral que Weber - corretamente, em sua opinião - atribui ao homem moderno. Essa disciplina seria, sobretudo, uma herança do pensamento de Erasmo, do qual Calvino teria se servido para pregar o retorno ao cristianismo primitivo, o estudo da Bíblia, a santificação da vida leiga e, sobretudo, a dedicação incondicional ao trabalho como forma superior de devoção religiosa. Especialmente esse último item, que Weber supunha ser o próprio cerne da "ética protestante", já era disseminado entre praticantes católicos "erasmianos" antes mesmo da Reforma (Trevor-Roper, 2007:54 e ss). Nessa perspectiva, diferentemente do que Weber supunha, o "novo homem" não teve de esperar pelo protestantismo ascético para ser concebido.

Admitindo-se que Trevor-Roper tenha razão, permanece a ideia de que "o velho" e "o novo" são claramente discerníveis e que a transição de um para outro requer necessariamente algo como uma "transformação da alma do homem". Requer, em outras palavras, uma ruptura espetacular com formas supostamente tradicionais de mentalidade. Neste artigo, são discutidas as dificuldades inerentes a essa ideia e a viabilidade de uma concepção de "novo homem" à margem dessas dificuldades.

\section{A RUPTURA COM O TRADICIONALISMO E O ADVENTO DE UM NOVO TIPO DE HOMEM}

Weber, sabidamente, jamais usou uma expressão como "novo homem" (embora, por outro lado, não se tenha furtado a usar expressões que denotem seu oposto, como "homem tradicional" e "homem pré-capitalista"), mas está claro que é disso que ele fala ao descrever, em termos típico-ideais, o modo como um hipotético empreendedor do ramo da indústria têxtil "convulsionou subitamente" a "vida de conforto e lazer" dos empreendedores de sua época (Weber, 1981:43 e ss) ${ }^{1}$.

Assim, conta-nos Weber, até meados do século XIX, os manufatureiros têxteis da Europa continental tinham uma vida relativamente confortável: trabalhavam apenas de cinco a seis horas por dia; seus ganhos eram moderados, mas o suficiente para assegurar-lhes uma vida respeitável; a competição entre eles não era acirrada, pois "havia um amplo acordo sobre as bases do negócio"; e cada qual podia se permitir 
uma "longa visita diária à taberna, com abundância de bebidas e um círculo aprazível de amigos". De repente, continua Weber, essa "situação idílica" vem abaixo. Um jovem manufatureiro, avesso aos hábitos tradicionais de seus contemporâneos, decide não esperar passivamente, como era até então usual, que os camponeses lhe trouxessem a matéria-prima (geralmente o linho) nem se sujeita, como era também habitual, ao esquema de venda por encomenda. Renunciando ao conforto do lar, dirige-se pessoalmente ao campo e "escolhe cuidadosamente tecelões para empregados, aumenta grandemente o rigor de sua supervisão sobre seu trabalho e transforma-os, assim, de camponeses em operários". Da mesma forma, em vez de produzir ao sabor das conveniências de um grupo habitual de fregueses intermediários, empenha-se em chegar diretamente a seus consumidores finais e, sobretudo, em ajustar a qualidade de seus produtos às demandas específicas desses consumidores. Em conexão com tudo isso, "introduz o princípio dos 'baixos preços' e de 'grande giro'", passando a ter vantagens sobre os demais manufatureiros. Uma "amarga luta competitiva" então se inicia, "fortunas respeitáveis são feitas e não emprestadas a juros, mas reinvestidas no próprio negócio", e quem não se adapta a esse novo modo de vida não tem também como conservar o anterior.

Com essa descrição típico-ideal, Weber vislumbra um cenário em que, pela primeira vez, o empreendimento econômico requer um padrão de conduta incompatível com "a velha atitude de lazer e conforto diante da vida" encontrável em qualquer época e em qualquer lugar. Enquanto essa "velha atitude" não foi espetacularmente rompida, tudo o que o empreendimento econômico requeria era uma aptidão comercial. Agora, em radical contraste, o que se requer do empreendedor é algo bem distinto, ou seja, "uma devoção total ao negócio", que passou a ser visto como um fim em si mesmo em vez de um mero meio de vida. Nos marcos desse raciocínio, a atividade comercial ou financeira, assim como a produção fabril em pequena escala, nada requer do empreendedor além do velho tino para os negócios. A atividade industrial em grande escala, em contraste, requer (ou, para ser mais preciso, requeria em seus primórdios) uma disciplina e uma capacidade de renúncia que somente o protestantismo em sua versão ascética, não luterana, teria sido capaz de proporcionar.

Nessa perspectiva, há um mundo de diferença entre dizer que determinado empreendedor tem uma aptidão especial para os negócios e dizer, desse mesmo empreendedor, que ele é "totalmente devotado ao 
próprio negócio". Aptidão comercial é algo que se tem ou não, independentemente do ambiente social em que se é criado. Já devoção ao negócio, tal como a exibida por nosso hipotético jovem empreendedor, pressupõe tanto uma personalidade quanto uma socialização muito especiais. Afinal, se quem se dedica a seu negócio com tamanha abnegação a ponto de "convulsionar" toda uma sedimentada "vida de conforto e de lazer" não tivesse uma personalidade fora do comum, a pressão dos que se percebessem prejudicados por seu modo de proceder acabaria por inviabilizar o novo padrão de empreendedorismo que veio, de fato, a se estabelecer. Por outro lado, esse novo padrão só pode ser criado por alguém que tenha recebido uma formação deveras especial; por quem tenha sido socializado em um ambiente no qual se aprende, desde tenra idade, que "tempo é dinheiro", que cada centavo gasto inutilmente representa a perda de uma grande soma após algum tempo, que um credor será complacente com o devedor se ouvir "o som de seu martelo às cinco da manhã e outro às oito da noite", mas será implacável "se ouvir sua voz em uma taberna", que "depois da industriosidade e da frugalidade nada contribui mais para um jovem ser bem-sucedido do que a pontualidade e a justiça em todos os seus negócios" e, mais importante do que tudo isso, que a infração a qualquer uma dessas regras não representa meramente a perda de uma boa oportunidade para enriquecer, mas constitui um repreensível descumprimento do dever (Weber, 1981:29-31)2. Em face de tudo isso, nosso hipotético manufatureiro inovador é sobretudo um homem que aprendeu a não retirar coisa alguma de sua riqueza para si mesmo, "a não ser a sensação irracional de haver 'cumprido' devidamente sua tarefa"; e, exatamente por essa razão, esse homem, esse novo homem "parece tão incompreensível e misterioso, tão sem valor e desprezível ao homem pré-capitalista" (ibid.:46-47).

Tal antagonismo entre o "homem pré-capitalista" e o "empreendedor moderno", ou, em termos mais gerais, entre o que quer que possa ser caracterizado como "o velho" e o que quer que possa ser caracterizado como "o novo" é, conforme já sugeri, um tema de inequívoca centralidade na obra de Weber. Assim, após descrever em termos típico-ideais o desmoronamento da (velha) "situação idílica" em que viviam os manufatureiros têxteis do século XIX, Weber faz questão de enfatizar que a entrada em cena do "primeiro inovador" é geralmente acompanhada de um "dilúvio de desconfiança, algumas vezes o ódio e, acima de tudo, de indignação moral" (ibid.:45). Nessas circunstâncias, é somente em razão de possuir um "caráter de força incomum" que o novo em- 
preendedor pode manter seu "autocontrole temperado" e se salvar de um "naufrágio tanto moral quanto econômico" (ibid.). Em outra passagem de sua obra, Weber faz referência a uma "típica antipatia da ética católica, seguida pela luterana, a toda tendência capitalista", antipatia essa que, segundo ele, "repousa essencialmente na repugnância da impessoalidade das relações peculiar à economia capitalista" (Weber, 2003:357). O termo "repugnância" aparece mais uma vez quando Weber descreve o modo como os empreendedores puritanos ingleses (cujo padrão de conduta pode muito bem ter servido de modelo para nosso hipotético manufatureiro inovador) repudiavam o tradicionalismo supostamente peculiar ao empreendedorismo judaico. Assim, Weber nos faz saber que, "de um modo característico, o judeu representava para o puritano inglês tudo o que lhe era repugnante, em razão de se dedicar a ocupações irracionais e ilegais como empréstimos para a guerra, arrendamento de impostos e ocupação de cargos públicos nos moldes dos protegidos da corte" (ibid.:367).

A bem da verdade, nem o caráter tradicional que Weber tão enfaticamente imputa à mentalidade luterana ao longo de toda a sua obra nem o escrúpulo antitradicionalista que, na citação acima, bem como em outras passagens de sua obra, imputa aos puritanos ingleses podem ser aceitos sem sérias reservas. Visto que é justamente o ato de fazer imputações de tal natureza que lhe permite postular o advento de um novo tipo de homem, é imperativo que nos detenhamos nessas imputações. Consideremos cada uma separadamente.

\section{A MENTALIDADE LUTERANA COMO FORMA DE TRADICIONALISMO A SER ROMPIDO}

"Exagerar é minha profissão." Conta-nos Gabriel Cohn que foi essa a resposta que Weber deu uma vez a um colega, a quem havia chocado com sua veemência em um debate (Cohn, 1982:7). Weber, de fato, exagerava, mas, para além disso, valia-se às vezes de exageros já disponíveis em sua Alemanha. Assim, o contraste preto no branco que estabelece, em incontáveis momentos de sua obra, entre as mentalidades luterana e calvinista, retratando a primeira como a própria expressão da passividade e a segunda como a própria expressão da atividade, é um bom exemplo de exagero cuja origem não são sua acuidade analítica nem seu pendor por descrições típico-ideais, mas sim o empenho de certos teólogos protestantes da primeira metade do século XIX em encontrar um meio de manter a unidade da Igreja protestante a despeito 
da variedade de credos ou de denominações existentes. Weber recebeu esse exagero pronto e acabado, já despojado de sua história e dos interesses pragmáticos que lhe deram origem, diretamente das mãos de um desses teólogos, a ser apresentado ao leitor já no próximo parágrafo. Se, entretanto, conhecermos um pouco da história desse exagero isto é, do modo como se chegou a conceber as diferenças entre as religiosidades luterana e calvinista em termos os mais antitéticos possíveis -, veremos que é um produto típico do pensamento teológico protestante da primeira metade do século XIX (digo primeira metade porque, já na segunda, Albrecht Ritschl, o mais influente teólogo protestante de língua alemã de seu tempo, havia vislumbrado uma maneira de conceber o luteranismo e o calvinismo em termos não antitéticos), sem validade para outros períodos; e, por essa razão, seu alcance heurístico é bem mais limitado do que os escritos de Weber nos levariam a supor ${ }^{3}$. Passemos, então, à história do referido exagero.

Tudo se inicia com o empenho do teólogo suíço Matthias Schneckenburger (1804-1848) em reunir as denominações protestantes de seu país, como já se fazia em vários territórios alemães protestantes nas décadas de 1820 e 1830 . Formado em teologia em uma das mais importantes escolas luteranas da Alemanha, o Tübinger Stift, na qual chegou a lecionar, e professor universitário em Berna, onde galgara, com apenas 30 anos, uma invejável posição, a cátedra de "dogmática comparada", Schneckenburger era, conforme se verá, particularmente talhado para essa difícil missão. Digo "difícil" porque a iniciativa de reunir os credos protestantes esbarrava muitas vezes em uma dura resistência. Assim, já em fins do século XVIII, havia uma denominação chamada "novos luteranos" que repudiava, por princípio, qualquer iniciativa dessa natureza. Tal denominação, embora não fosse contemporânea de Schneckenburger, foi uma importante fonte de inspiração para gerações posteriores de teólogos luteranos e de praticantes luteranos leigos, para quem um trabalho como o de Schneckenburger poderia destruir as verdades mais recônditas da tradição luterana. Schneckenburger tinha como certo que, sem vencer a resistência desses grupos, desses herdeiros do "novo luteranismo", qualquer iniciativa visando à reunião de credos estaria fadada ao fracasso.

Posto o problema, Schneckenburger só vislumbrava uma solução: expor as profundas diferenças doutrinais existentes entre os credos protestantes - uma tarefa sob medida para ele próprio, um professor de "dogmática comparada". A bem da verdade, as diferenças doutrinais, 
em si mesmas, não lhe importavam muito, porque, de seu ponto de vista, as diferenças verdadeiramente importantes eram as de natureza psicológica. Schneckenburger acreditava que doutrinas diferentes encerravam "estados mentais", ou "estados de consciência religiosa", específicos, os quais, por seu turno, se refletiam em práticas religiosas distintas. Nessa perspectiva, o conhecimento das doutrinas teológicas, ou dos dogmas peculiares a cada denominação, era importante tão somente como via de acesso aos "estados de consciência religiosa" que supostamente lhes eram subjacentes. Para os propósitos da presente discussão, é suficiente mencionar, mesmo incorrendo em uma flagrante simplificação, que Schneckenburger distinguia esses "estados" em duas categorias: os "passivos" e os "ativos". Uma vez estabelecida essa distinção, a questão que se instalava era identificar o tipo de "estado mental" que predominava em cada denominação. A resposta Schneckenburger foi buscar no exame das doutrinas calvinista e luterana a respeito dos temas que, segundo ele, eram os mais diretamente afeitos ao cristianismo: conversão, santificação e salvação. Saibamos imediatamente sua conclusão: no calvinismo, "os estados ativos prevalecem sobre os passivos"; no luteranismo, a "consciência quiescente" predomina (Schneckenburger [1855] apud Graf, 1993:38-39).

Foi então, dessa forma, que o luteranismo e o calvinismo passaram a ser contrastados nos termos da antítese "passividade" versus "ativida$\mathrm{de}^{\prime \prime}$. Weber recolheu essa antítese diretamente dos escritos de Schneckenburger e a incorporou sem reservas a seu próprio pensamento ${ }^{4}$. Assim, não foi uma investigação histórica a respeito do modo como o luteranismo e o puritanismo efetivamente vieram a se distinguir que o conduziu à conclusão de que havia um antagonismo entre ambos. Suas fontes teológicas, notadamente Schneckenburger, levaram-no a supor que esse antagonismo estava dado desde sempre, em razão das profundas diferenças entre os ensinamentos doutrinários de Lutero e Calvino. Com efeito, de acordo com a concepção de vocação de Lutero, "o indivíduo deve fundamentalmente permanecer na profissão e na posição em que Deus originalmente o colocou, e sua aspiração deve se manter dentro dos limites dessa sua condição de vida" (Weber, 1981:57). Para Calvino, em contraste, sendo o indivíduo nada mais do que uma espécie de administrador dos bens divinos na Terra, ele deve fazer o que tiver a seu alcance para ampliar esses bens. Revelar-se, digamos assim, um administrador bem-sucedido é o meio de se saber um eleito, ou predestinado, à bem-aventurança. Nessa perspectiva, um indivíduo que se satisfaz com sua posição estaria, na verdade, contrari- 
ando a vontade divina. Essas diferenças, acreditava Weber, iriam se refletir necessariamente em diferenças no modo de se conduzir na vida cotidiana. A conduta de seu hipotético manufatureiro inovador, por exemplo, seria típica de quem absorveu a concepção calvinista de vocação. Os demais manufatureiros hipotéticos, acomodados que eram à "velha vida de conforto e lazer", exibiam um comportamento típico de alguém que jamais a absorveu. Entre o primeiro e os últimos haveria, assim, algo como um abismo, e os preceitos calvinistas exemplificados pela pregação de Benjamin Franklin ${ }^{5}$ seriam como uma "plataforma de lançamento" a partir da qual se daria o salto de uma das margens desse abismo à outra. Nessa linha de raciocínio, nenhuma continuidade poderia ser admitida entre as religiosidades luterana e calvinista.

Ocorre, entretanto, que a literatura especializada de nossos dias é um tanto impiedosa com essa linha de raciocínio porque, ainda que se admita a existência de um fosso entre o luteranismo e o calvinismo na Alemanha de Schneckenburger (algo, em si mesmo, discutível) e, uma geração mais tarde, na Alemanha de Weber, esse fosso, longe de ser um corolário das diferenças doutrinárias, foi o resultado de um processo bastante gradual, que requereu um árduo trabalho de doutrinação a várias gerações sucessivas. Afinal, se mesmo após a Guerra de Trinta Anos, em plena década de 1650, mal existia uma fronteira confessional entre o luteranismo e o calvinismo, o que dizer então de um fosso (ou mesmo um abismo) entre ambos?

É verdade que posições dogmáticas separaram os luteranos e os calvinistas da primeira geração, mas já não mais o fizeram a partir da segunda, que estava prioritariamente interessada em reformar a própria conduta cotidiana. Conforme assinala Hartmut Lehmann (1987), um destacado estudioso do assunto, para essa geração, ou melhor, para toda uma geração de pregadores protestantes da virada do século XVI para o XVII, a reforma da doutrina cristã, tal como realizada por Lutero e Calvino, deveria ser seguida por uma segunda reforma, "a reforma da vida", e nada servia melhor a esse propósito do que a produção em massa de tratados devocionais, os quais eram escritos, impressos e vendidos não às dúzias, mas às centenas e aos milhares. $O$ ponto a ser destacado aqui é que, para os autores desses tratados, os limites confessionais eram praticamente irrelevantes, pois os calvinistas se valiam de escritos luteranos e vice-versa; ambos, por seu turno, valiam-se de fontes católicas do medievo tardio e, "mais significativamente, os autores ingleses eram frequentemente traduzidos para outras línguas, 
sobretudo o alemão, com autores holandeses frequentemente fazendo a mediação" (ibid.:314; tradução minha). Nessa perspectiva, "embora as posições dogmáticas das Igrejas do século XVII fossem bem diferentes, o que elas ensinavam no campo da ética do dia a dia era mais ou menos a mesma coisa: conscienciosidade, seriedade moral, diligência" (ibid.:315; tradução minha).

Curiosamente, já na primeira metade do século XIX, vários dogmatistas calvinistas contemporâneos de Schneckenburger sustentavam, em conformidade com o que os especialistas asseveram em nossos dias, não haver nenhuma conexão intrínseca entre o conteúdo de uma doutrina e a conduta moral do devoto. De acordo com esses dogmatistas, a doutrina calvinista da predestinação, por exemplo, era apenas uma concepção dogmática dos eruditos, abstrata demais para exercer qualquer influência significativa sobre a conduta cotidiana (Graf, 1993:39). Weber conhecia o trabalho desses dogmatistas e se prontificou a rebatê-los - em uma longuíssima e indispensável (para seu argumento geral) nota de rodapé ${ }^{6}$. No entanto, em uma importante passagem de $A$ Ética Protestante e o Espírito do Capitalismo, Weber acaba por dar a mão à palmatória, ainda que involuntariamente. Refiro-me a uma passagem na qual ele descreve o modo como os alemães de seu tempo concebiam "o tipo ideal de empreendedor capitalista". Eles o representavam como alguém que "evita a ostentação e as despesas desnecessárias, assim como o gozo consciente de seu poder, e embaraçam-no os sinais de reconhecimento social que recebe. Em outras palavras, seu modo de vida distingue-se frequentemente [...] por uma certa tendência ascética, como aparece de modo bastante claro na pregação de Franklin" (Weber, 1981:46-47).

Ao discutir a concepção luterana de vocação, o próprio Weber havia asseverado que "Lutero teria, sem dúvida, repudiado violentamente qualquer parentesco com uma mentalidade como a de Franklin" (id., ibid.:54). Se é assim, como poderia a conduta do empreendedor capitalista típico de sua Alemanha luterana "distinguir-se" justamente "por uma tendência ascética, tal como aparece de modo bastante claro na pregação de Franklin"? Receio de que só há uma solução para esse enigma: as diferenças doutrinárias não se refletiam em diferenças significativas de mentalidade. Em resumo, entre as religiosidades luterana e calvinista não havia necessariamente o abismo que Schneckenburger, sua principal fonte teológica, levou-o a supor haver. 


\section{O ESTILO JUDAICO DE EMPREENDEDORISMO COMO FORMA DE TRADICIONALISMO A SER ROMPIDO}

Uma vez expostas as dificuldades envolvidas em conceber as mentalidades luterana e calvinista como se estivessem necessariamente separadas por um abismo, passo agora a discutir a pertinência da tese weberiana de que um abismo da mesma natureza separa o empreendedorismo calvinista do judaico. Weber, conforme vimos, postula a existência de tal abismo ao afirmar que "de um modo característico, o judeu representava para o puritano inglês tudo o que lhe era repugnante, em razão de se dedicar a [todo um conjunto de] ocupações irracionais e ilegais" (2003:381; tradução minha). A lista de "ocupações irracionais e ilegais", recapitulemos, é composta de itens da seguinte natureza: empréstimo para a guerra, arrendamento de impostos e de cargos públicos, e envolvimento em "contratos governamentais, monopólios estatais, promoções especulativas, construção e projetos financeiros dos príncipes" (Weber, 1981:213).

Infelizmente, dessa vez, Weber não citou suas fontes; portanto, ninguém pôde reconstruir a história da ideia de que os puritanos ingleses repudiavam os judeus em razão de estes últimos se envolverem em práticas como as listadas acima. De qualquer forma, o que sabemos a respeito, seja da natureza do empreendedorismo calvinista do século XVII, seja das razões de Cromwell para readmitir a entrada dos judeus na Inglaterra, de onde haviam sido expulsos em 1290, leva-nos a duvidar seriamente desse antagonismo que Weber afirma haver entre os estilos judaico e calvinista de empreendedorismo. Não obstante, ainda que se admita a existência de tal antagonismo, não há indícios de que ele possa ser um resultado necessário de diferenças entre as concepções religiosas judaica e calvinista.

Iniciemos por um ponto incontroverso: Weber estava indubitavelmente correto ao afirmar que os judeus eram dados a toda sorte de ocupações "irracionais e ilegais". Contudo, o que dizer dos calvinistas? Em $A$ Ética Protestante, Weber os retrata como comprometidos com o "rijo legalismo" e a "ativa empresa dos empreendedores capitalistas burgueses" (1981:98). Infelizmente, um quadro magnífico do empreendedorismo calvinista do século XVII, tal como o nos apresentado por Trevor-Roper (2007), mostra que, dessa vez, Weber errou o alvo por uma boa distância. Sigamos, então, o roteiro de Trevor-Roper, que se inicia pelos países escandinavos. 
No fim da década de 1620 e no início da década de 1630, os maiores defensores políticos da causa protestante eram os dois reis luteranos da Escandinávia - Cristiano IV, da Dinamarca, e, após sua derrota, Gustavo Adolfo, da Suécia. Ambos estavam empenhados em intervir na Europa e, para tanto, viram-se obrigados a mobilizar recursos industriais e financeiros. Isso significava recorrer a grandes capitalistas. Recorrer a quem, mais especificamente? Deixemos que o próprio Trevor-Roper nos conte a história:

Cristiano IV voltou-se imediatamente para uma firma calvinista em Amsterdam, dos irmãos De Willem. Jan de Willem, em Copenhague, era um dos fundadores da Companhia Dinamarquesa das Índias Orientais. Seus irmãos Paul e David estabeleceram-se em Amsterdam e, através do mercado financeiro internacional, forneciam crédito para a compra de armas. Quando os irmãos De Willem deixaram de trabalhar para ele, Cristiano IV procurou outra família calvinista, de origem flamenga, a família Marcelis, que já havia construído um império comercial no norte. De início, tratava-se de um império cosmopolita. Procuraram monopolizar o cobre sueco, negociavam o cobre norueguês do rei da Dinamarca e trigo e armas do czar da Rússia. Mas no final apoiaram a Dinamarca. Na década de 1640, os irmãos Gabriel e Celio Marcelis eram conselheiros econômicos, fornecedores, financistas, negociantes de munição e exportadores de munição do rei da Dinamarca. Antecipavam dinheiro sobre as taxas de cobre. Criaram frotas. Em torno deles, a aristocracia luterana nativa decaiu para simples proprietários de terra e os negociantes nativos tornaram-se meros agentes das casas comerciais calvinistas holandesas. Os calvinistas holandeses tornaram-se, de fato, uma nova aristocracia capitalista na Dinamarca luterana (ibid.:31-32).

Essa passagem deixa claro que, em matéria de devoção a "ocupações irracionais e ilegais", nossos calvinistas do século XVII, sobretudo os irmãos Marcelis, nada deixavam a desejar. Somente se impressiona com esses irmãos quem não foi ainda apresentado a Louis de Geer, um calvinista de Liège, também estabelecido em Amsterdã, a quem o rei da Suécia recorreu para enfrentar a Dinamarca. Se Weber tivesse sido apresentado a calvinistas do calibre de De Geer, certamente teria hesitado em se referir ao empreendedorismo calvinista como tipicamente "ativo" e "capitalista burguês". Com efeito, nosso calvinista de Liège era a própria personificação do tradicionalismo e do irracionalismo que Weber supunha típicos de um empreendedor judeu. Assim, para 
início de conversa, "todas as indústrias de cobre e de ferro na Suécia estavam em suas mãos, e com elas supria os exércitos e frotas não apenas da Suécia, mas também da Holanda, França, Veneza, Portugal, Inglaterra, Escócia, Rússia e os príncipes alemães" (ibid.:33). Nada mal, não é verdade? Prossigamos: "Em 1645 reuniu, fretou e equipou uma esquadra naval para servir à Suécia contra a frota que seu parente Gabriel Marcelis tinha, do mesmo modo, criado para a Dinamarca. Em paga por seus empréstimos à Coroa sueca, recebeu consignações de cobre, arrendamento de terras da Coroa, taxas alfandegárias, privilégios, isenções, títulos de honra" (ibid.). A bem da verdade, a lista das "ocupações irracionais e ilegais" atribuíveis a De Geer é bem mais longa, mas não devemos negar espaço a outros calvinistas.

Os irmãos Abraham e Jacob Momma, por exemplo, abriram minas de ferro e cobre na Lapônia e se tornaram financistas pessoais da rainha Cristina. Os irmãos Spiering controlavam o mercado de trigo e arrendavam os impostos do Báltico. Se nos voltarmos para os países católicos - França, Áustria e Espanha -, o quadro é rigorosamente o mesmo. Cada um desses países tem empreendedores calvinistas à altura de nosso Louis de Geer. Em todos eles, até mesmo na Espanha católica de Filipe IV, eram os empreendedores calvinistas os mais importantes financistas, monopolizadores, enfim, tudo aquilo que seus correligionários ingleses repudiavam como uma peculiaridade judaica ${ }^{7}$.

Diante desse quadro, por que os puritanos ingleses seriam tão escrupulosos em relação ao "irracionalismo" do empreendedorismo judaico? Não me parece muito verossímil que quem tenha em suas hostes um Louis de Geer, um Hans de Witte, um Barthélemy d'Herwarth ${ }^{8}$, entre muitos outros, possa se espantar com o modo de atuar de um judeu. Assim, se, conforme Weber assevera, havia mesmo por parte dos puritanos ingleses um repúdio aos judeus, a razão para esse repúdio não podia ser o envolvimento desses últimos em "ocupações irracionais e ilegais", pois, no que se refere a esse quesito, seus correligionários eram, pelo menos no século XVII, imbatíveis. Retorno a esse ponto na próxima seção.

Por outro lado, a própria existência desse alegado repúdio é algo que merece ser mais bem examinado. Como é sabido, foi justamente no esteio da chamada revolução puritana que os judeus puderam retornar em massa à Inglaterra, de onde haviam sido expulsos em 1290. Nota-se, nesse caso, que as "ocupações irracionais" às quais os judeus se 
dedicavam, notadamente o monopólio do comércio inter e transcontinental (o que incluía o comércio com o Brasil), longe de terem sido um motivo de repúdio, foram, justamente, uma importante razão para Cromwell querer tê-los em sua República. Cromwell considerava o empreendedorismo judaico, a despeito de todo o seu "irracionalismo", ou, talvez, exatamente por causa dele, de extrema importância para a continuidade do sucesso comercial advindo do Ato de Navegação de 1651 - o qual, diga-se de passagem, nada tem de "capitalista racional-burguês" ${ }^{\prime}$. Em face de tudo isso, há algo de estranho em relação à alegada "repugnância" puritana ao estilo de empreendedorismo praticado pelos judeus, pois isso jamais impediu aos puritanos de contar com os frutos desse empreendedorismo.

Isso posto, vale acrescentar que, conforme mostra o trabalho do historiador Ellis Rivkin a respeito do empreendedorismo marrano-judaico no século XVI, havia, nessa época, um perfeito entrosamento entre os empreendedores marranos radicados na Turquia - notadamente a figura legendária do Duque de Naxos, um megaempreendedor judeu que foi, para Selim II, sultão do Império Otomano no período 1566-1577, o que o já citado Louis de Geer viria posteriormente a ser para o rei Gustavo Adolfo da Suécia - e os empreendedores calvinistas dos Países Baixos. Antes de serem judeus ou calvinistas, eram todos eles empreendedores, não havendo nenhum antagonismo entre suas respectivas mentalidades ou modo de proceder ${ }^{10}$.

\section{WEBER E A DEMANDA POR ANTAGONISMOS IRREMEDIÁVEIS E RUPTURAS ESPETACULARES}

Uma vez estabelecido que nem as mentalidades luterana e calvinista nem os estilos judaico e puritano de empreendedorismo estão necessariamente separados por um abismo, cumpre mostrar que essa demanda de Weber por abismos, cuja transposição requer algum salto espetacular (como o que Weber supunha ter sido proporcionado pela doutrina calvinista da predestinação), não é um traço incidental de seu pensamento. Receio de que haja uma maneira particularmente privilegiada de fazê-lo: mostrar quanto o raciocínio sociológico weberiano se assemelha ao raciocínio aristotélico a respeito das relações entre o repouso e o movimento. Parece-me que, uma vez cientes dessa semelhança, podemos compreender melhor a necessidade de purgar a discussão a respeito da emergência do novo da demanda, peculiar ao pensamento weberiano, por antagonismos irremediáveis e rupturas espetaculares. 
Como é sabido, a física aristotélica postula a existência de um "estado natural", o do repouso, do qual um dado corpo (seja uma mesa, uma cadeira, um lápis ou o planeta Terra) só pode se afastar se for perturbado por alguma força que lhe é estranha. Quando a perturbação cessa, o corpo volta a seu "estado natural". Nessa perspectiva, o movimento é tão somente o resultado de uma perturbação do repouso, requerendo, como tal, alguma explicação especial. O repouso, em si mesmo, sendo o "estado natural", não requer explicação alguma. Assim, que uma mesa permaneça em repouso não é algo que requeira explicação especial. Se ela se desloca, aí, sim, uma explicação é requerida: alguém a empurrou, por exemplo.

No pensamento de Weber, encontramos algo rigorosamente análogo tanto ao estado de repouso quanto às forças que o perturbam a fim de produzir o movimento. O análogo sociológico do repouso é aquilo que Weber chama, seguidamente, de "tradicionalismo", essa "falta generalizada de capacidade e de disposição para se afastar de caminhos batidos" (2003:355; tradução minha). Da mesma forma que o repouso de Aristóteles, o tradicionalismo, esse apego generalizado a "caminhos batidos", é algo do qual, na perspectiva weberiana, só se pode afastar por meio de rupturas bruscas, ocasionadas pelo efeito perturbador de algum agente externo, e a ele se retorna sempre que o efeito perturbador cessa de operar. Assim, quando Weber faz menção à "velha atitude de conforto e lazer para com a vida" dos primeiros empreendedores capitalistas, à "consciência quiescente" dos luteranos ${ }^{11}$ e ao "irracionalismo" do empreendedorismo judaico, não está fazendo outra coisa senão oferecer exemplos de "caminhos batidos" em relação aos quais há uma "falta generalizada de capacidade e de disposição para se afas$\operatorname{tar}^{\prime \prime 12}$. Quando, por outro lado, faz menção ao "ascetismo intramundano" peculiar ao empreendedor moderno, à concepção calvinista de vocação e ao escrúpulo puritano em relação aos judeus, está, sobretudo, oferecendo exemplos de forças que, por algum tempo, perturbaram ou se contrapuseram, com sucesso, à "falta generalizada de capacidade e de disposição para se afastar", respectivamente, da "velha atitude de conforto e lazer para com a vida", da "consciência quiescente" e das "ocupações irracionais e ilegais" listadas anteriormente.

Dessa forma, na sociologia da religião de Weber, o mundo é composto de corpos em repouso, de um lado, e de forças que o perturbam (às vezes com duradouro sucesso, às vezes nem tanto), de outro. Em um mundo composto dessa maneira, no qual ou bem se está em repouso, 
ou bem se está perturbando esse repouso; ou bem se é tradicional (o judaísmo, o catolicismo, o luteranismo), ou bem se está inovando (o protestantismo ascético e o sectarismo que se lhe tornou peculiar), o que mais, além de "antipatia", "desprezo", "repugnância", em resumo, um irremediável antagonismo, pode haver entre quem está em lados (vistos como) inequivocamente opostos, entre quem está aquém e quem está além de uma pretensa ruptura espetacular? Que um suposto "homem tradicional" e um suposto "novo homem" se hostilizem mutuamente se torna, então, algo tão natural quanto o é, para Aristóteles, o fato de uma mesa permanecer em repouso a menos que seja empurrada. Como Weber tinha isso como certo, pareceu-lhe tão natural constatar que os puritanos repudiavam os judeus que, em vez de se perguntar pelas razões sócio-históricas desse repúdio ${ }^{13}$, ele tomou como sua a explicação que os próprios puritanos ofereciam para isso, acabando, assim, por encampar a imagem complacente que eles tinham de si próprios (algo como "nós, diferentemente dos judeus, não nos envolvemos com especulações, monopólios, guerras etc.").

Nos marcos desse raciocínio, qualquer investigação a respeito das razões para uma constatada hostilidade entre judeus e puritanos, ou entre luteranos (ou católicos) e calvinistas, torna-se, de saída, dispensável, porque já se imagina, de antemão, que qualquer hostilidade que se venha a constatar é apenas um caso especial de uma forma mais geral de hostilidade, ou seja, a que necessariamente resulta da incompatibilidade entre o apego generalizado a "caminhos batidos" e um esforço deliberado para se afastar desses caminhos - para falar com Aristóteles, entre um corpo em seu estado natural, o repouso, e uma força perturbadora potencialmente capaz de colocá-lo em movimento.

Na medida em que constitui uma mera expressão da "falta generalizada de capacidade e de disposição" para mudar, um empreendedorismo tal como o praticado pelos judeus não requer, na perspectiva weberiana, nenhuma explicação. Seria algo como um corpo em seu estado natural, o repouso. Em claro contraste, o empreendedorismo puritano seria como um corpo em movimento. Como o movimento não é um estado natural, mas produzido e mantido por uma ou mais forças perturbadoras, tratar-se-ia, então, de identificar essas forças. Foi o que Weber se prontificou a fazer. Uma dessas forças é óbvia demais para merecer qualquer comentário adicional. Refiro-me, evidentemente, à doutrina calvinista de que o sucesso decorrente de uma vida dedicada ao traba- 
lho é a "prova" da predestinação à bem-aventurança. Se essa doutrina (ou, para ser mais preciso, os prêmios psicológicos que supostamente dela advêm) é a força que pode afastar o devoto de "caminhos batidos", como a passividade política luterana, de um lado, e o "irracionalismo" judaico na condução dos assuntos econômicos, de outro, outra força é necessária para que tal afastamento, uma vez ocorrido, possa ser mantido através das gerações. Refiro-me, agora, ao caráter sectário que o protestantismo ascético veio a assumir. Se não fosse pelas injunções impostas pelas seitas protestantes ${ }^{14}$, acreditava Weber, a viabilidade de um empreendedor moderno como nosso hipotético manufatureiro inovador estaria seriamente comprometida. Era justamente à ausência dessas seitas em sua Alemanha que Weber creditava a passividade política da burguesia alemã diante do autoritarismo político-cultural do Império Guilhermino ${ }^{15}$.

Mas, o que há de tão especial em relação às seitas? A resposta é bem conhecida: diferentemente de uma Igreja, que aceita seus membros sem nada procurar saber a respeito de sua vida pregressa, as seitas condicionam a admissão "a uma estrita investigação a respeito da conduta ética de quem se apresenta" (Weber, 2003:366; tradução minha). Em decorrência, ser aceito por uma seita é como receber um certificado de probidade. Nessa perspectiva, se nosso hipotético manufatureiro inovador é o exemplo paradigmático do "novo homem", isso não se deve fundamentalmente ao fato de ele ser o empreendedor inteiramente devotado ao negócio que Weber descreveu, mas, sobretudo, ao fato de se tratar de alguém cujo ascetismo, "ao mesmo tempo íntimo e voltado para o mundo" 16 , assegurar-lhe-ia a admissão em qualquer seita protestante. Como na Alemanha de Weber essas seitas já não existiam mais, sua referência empírica eram as seitas cujos cultos teve a oportunidade de frequentar e cujos membros teve a oportunidade de conhecer ao visitar os Estados Unidos em 1904. Ao mesmo tempo que o alegrava constatar que, em várias cidades americanas, nem mesmo um banqueiro ou um médico poderia "fixar residência ou estabelecer contatos importantes sem que lhe perguntassem a que comunidade religiosa pertencia, e sem que suas chances de sucesso dependessem da natureza de sua resposta" (id., ibid.), aterrorizava-o - como ele próprio diria em carta endereçada ao teólogo Adolf von Harnack, datada de 5 de fevereiro de 1906 - admitir que, em sua Alemanha, "o tempo das seitas, ou de algo equivalente a elas, já [estivesse] definitivamente acabado"17. 


\section{TRANSIÇÕES SEM RUPTURAS ESPETACULARES}

Se, em 1904, Weber se alegrava ao saber que, em muitas cidades americanas, o pertencimento a uma seita poderia ser decisivo para as chances de sucesso até mesmo de um banqueiro ou de um médico, houve quem, cerca de duzentos e trinta anos antes, para ser mais preciso, em 1670 , se rejubilasse exatamente pelo motivo oposto, isto é, por se saber natural de uma cidade em que nenhuma importância se dava ao fato de alguém pertencer ou não a alguma seita. Refiro-me a ninguém menos que Espinosa e sua próspera e palpitante Amsterdã. Nas últimas páginas de seu Tratado Teológico-Político, Espinosa conclui um argumento a respeito da liberdade de opinião nos seguintes termos:

Basta ver como a cidade de Amsterdam, com o seu extraordinário desenvolvimento e a admiração que se lhe consagram todas as nações, está colhendo os frutos dessa liberdade! De fato, nesta fluorescente república e nobilíssima cidade, todos os homens, seja qual for a sua nação ou a sua seita, convivem na mais perfeita harmonia e não fazem perguntas antes de confiar seus bens a um concidadão, exceto se ele é rico ou pobre e se costuma agir de boa ou de má-fé. Quanto ao resto, a que religião ou seita pertence, isso não lhes interessa, visto não contar rigorosamente nada, perante o juiz, para se ganhar ou perder uma causa. E não existe absolutamente nenhuma seita, por mais odiada que seja, cujos membros (desde que não prejudiquem ninguém, deem a cada um o que lhes é devido e vivam honestamente) não sejam protegidos pela autoridade dos magistrados e pela guarda (2003:308; ênfases minhas) ${ }^{18}$.

O contagiante entusiasmo com que Espinosa descreve a liberdade religiosa que impera em sua Amsterdã é bem característico de quem se vê diante de algo inequivocamente novo ${ }^{19}$. Com sua ajuda, poderíamos conceber "o novo" como residindo não somente, como quer Weber, no controle social que as seitas protestantes, ou algo que se lhes pudesse equivaler, puderam um dia exercer sobre seus membros para selecionar atributos como autocontrole, frugalidade e industriosidade - sem os quais, acreditava Weber, "o capitalismo de hoje, mesmo na América, não seria o que é" (1974:355) -, mas também na tolerância exibida pelo amsterdamês do fim do século XVII, ela própria condicionada à existência de uma autoridade constituída (a "autoridade dos magistrados").

Weber, entretanto, não pôde admitir essa possibilidade. Em sua sociologia da religião, conforme vimos, o novo é algo que se produz, ou a 
que se tem acesso, somente por meio de uma força que perturbe algum análogo sociológico do corpo em repouso. Nessa perspectiva, só seria possível atribuir o caráter de novidade a alguma coisa se fosse possível apontar o análogo sociológico tanto do repouso quanto da força que o perturbou para propiciar o surgimento dessa coisa. Se, por exemplo, Weber pôde atribuir o caráter de novidade aos atributos listados anteriormente (autocontrole, frugalidade e industriosidade), foi somente porque, em primeiro lugar, lhe foi possível apontar os análogos sociológicos tanto do corpo em repouso quanto da força que o perturbou para propiciar o surgimento desses atributos. Tais análogos seriam, respectivamente, a "velha atitude de conforto e lazer diante da vida" e a doutrinação calvinista, tal como exemplificada pela pregação de Benjamin Franklin. Para atribuir à tolerância um caráter de novidade, Weber teria de, da mesma forma que no caso anterior, ser capaz de apontar tanto o "corpo" que teria sido "perturbado" quanto a "força" que teria provocado a "perturbação" para conduzir a seu advento. Como não lhe foi possível, dessa vez, apontar nem uma coisa nem outra, e como não é possível, nos marcos de sua sociologia da religião, atribuir o caráter de novidade a coisa alguma a menos que se identifiquem esses dois elementos, ele jamais poderia ver a tolerância como uma novidade. De fato, não viu. Em uma nota de rodapé extremamente longa de A Ética Protestante, Weber faz questão de asseverar que "a tolerância religiosa não é peculiar aos tempos modernos, nem ao Ocidente" ${ }^{20}$. Não obstante, nessa mesma nota, Weber assevera que "o primeiro a destacar-se em defesa da tolerância absoluta, e da separação entre a Igreja e o Estado, quase uma geração antes dos Batistas, e quase duas antes de Roger Williams, foi John Browne" (1981:187). Ao fazê-lo, Weber quis chamar a atenção para o fato de que o sectarismo protestante é a via de acesso por excelência a uma tolerância genuinamente religiosa - cuja mais alta expressão teria sido o pensamento teológico de um Roger Williams ${ }^{21}$.

Com efeito, Weber vislumbra três tipos de tolerância: 1) de natureza econômica, na qual se admite a devoção a outras religiões como meio de obter vantagens financeiras; 2 ) de natureza política, na qual se admite a devoção a outras religiões como uma forma de obter aliados estratégicos em circunstâncias determinadas; 3) de natureza propriamente religiosa, ou "tolerância absoluta", na qual se admite a devoção a qualquer religião com base no pressuposto de que é da vontade de Deus que se o faça. Para Weber, o sectarismo constituiria, por assim di- 
zer, o terreno propício para a germinação da aludida tolerância genuinamente religiosa. $\mathrm{O}$ trecho abaixo mostra isso com clareza:

\begin{abstract}
A seita pura deve advogar a "tolerância" e a "separação entre a Igreja e o Estado" por várias razões: porque ela não é uma instituição redentora universal para a repressão dos pecados nem pode suportar o controle e a regulamentação política ou hierocrática; porque nenhum poder oficial - seja de que classe for - está autorizado a dispensar bens de salvação ao indivíduo, de sorte que todo o emprego do poder político em coisas religiosas é considerado insensato, ou melhor, demoníaco; porque as seitas simplesmente não se interessam por quem não faz parte dela; porque, considerando tudo isso em conjunto, a seita mesma - se não quiser renunciar ao íntimo sentido religioso de sua ação - não pode ser mais do que uma associação livre de pessoas especificamente qualificadas do ponto de vista religioso. Portanto, as seitas consequentes têm sempre representado esse ponto de vista e são as mais enérgicas defensoras da "liberdade de consciência" (Weber, 1968:1208; tradução minha $)^{22}$.
\end{abstract}

Mesmo admitindo que as "seitas consequentes" têm sido "as mais enérgicas defensoras da 'liberdade de consciência'", permanece sem resposta a questão de que importância elas (por mais "consequentes" que possam ter sido) efetivamente tiveram para o desenvolvimento da tolerância genuinamente religiosa. Afinal, ainda que se admita que a história da tolerância religiosa se tenha iniciado com as pregações do obscuro John Browne ${ }^{23}$, essa história não se encerra com as pregações de Roger Williams. Um capítulo fundamental do desenvolvimento posterior dessa história é, sabidamente, o aparecimento do clássico tratado de Locke a respeito da tolerância, em 1689, e não há indícios de que o sectarismo protestante tenha tido alguma importância significativa para o desenvolvimento da perspectiva de Locke sobre a tolerân$\mathrm{cia}^{24}$. Se pouca ou nenhuma importância teve para o pensamento de Locke, menos ainda o teve para o pensamento de um Espinosa ${ }^{25}$, que representou um passo à frente em relação ao primeiro: enquanto Locke defendia a ideia de uma "soberania dual", isto é, um Estado e uma Igreja igualmente soberanos, Espinosa "chegou a uma concepção mais profunda da tolerância ao subordinar a Igreja ao Estado. Dessa forma, transformou o Estado na única autoridade legítima entre os homens" ${ }^{26}$. Por outro lado, se voltarmos nossa atenção para a Europa Ibérica, veremos que ali se desenvolveu uma tradição de tolerância genuinamente religiosa inteiramente à margem de qualquer forma de sectarismo 
ou congregacionalismo. É melhor passarmos a palavra a um estudioso do assunto:

[No século XVII] havia na Espanha e em Portugal uma velha tradição de tolerância que tinha raízes tanto em controvérsias teológicas medievais, a respeito da lei natural e da possibilidade de salvação universal através da graça divina, quanto em um tipo de sabedoria prática camponesa segundo a qual levar a vida de acordo com os mandamentos de Deus era suficiente para assegurar a salvação. Esta sabedoria prática se exprimia em máximas como "melhor um bom mouro que um mau cristão" ou "cada um pode se salvar na sua própria lei". Estas ideias latitudinárias seriam exemplos do que a Inquisição chamava de "proposições", isto é, concepções que conflitavam diretamente com o dogma pós-tridentino tal como ela os representava e defendia. Essas "proposições" incluíam um amplo espectro de crenças desviantes: a negação do paraíso, inferno e purgatório, a dúvida em relação à virgindade de Maria ou da eficácia dos santos, a crença de que não havia pecado no sexo pré-marital e, mesmo, a própria negação da existência de Deus. Dentre essas ideias, havia também a crença de que a salvação era acessível a todos os que levassem uma vida de bem, independentemente de sua religião. Embora estas ideias relativistas pudessem ser encontradas entre judeus e muçulmanos convertidos, elas não eram de forma alguma associadas somente a eles (Schwartz, 2003:35).

Diante disso, claro está que há vias não sectárias de acesso à "tolerância absoluta" e, mais importante, essas vias, ao contrário do que a passagem de Weber anteriormente reproduzida sugere, não são mais estreitas do que as sectárias. Talvez sejam até mais largas ${ }^{27}$. A Europa Ibérica, por exemplo, não precisou esperar por "seitas consequentes" para desenvolver sua própria tradição genuinamente religiosa de tolerância. Foi contra o pano de fundo dessa tradição, diga-se de passagem, que a figura legendária do padre Antônio Vieira pôde emergir. Quando, em nossos dias, o tomamos como o exemplo paradigmático da tolerância no Brasil seiscentista, não nos ocorre que a tolerância que apregoava pudesse ser "na verdade, mais limitada e mais 'instrumental' que a de alguns de seus contemporâneos e predecessores" (id., ibid.:34) $)^{28}$.

Isso posto, gostaria de sugerir que, para além dos três tipos de tolerância vislumbrados por Weber - econômica, política e genuinamente religiosa (ou "absoluta") -, há um quarto tipo que não ocorreu a ele justamente por se tratar de um claro exemplo de novidade sem nenhuma re- 
lação com a disciplina mental e moral demandada pelo sectarismo protestante. Em outras palavras, sem relação alguma com a "transformação da alma do homem" decorrente do advento da demanda por tal disciplina. Refiro-me ao que poderia ser chamado de a tolerância pela tolerância, ou a tolerância como um fim em si mesmo. Esse tipo de tolerância, entretanto, não é análogo à concepção protestante do trabalho como um fim em si mesmo porque, diferentemente desta última, em nada depende de "sensações irracionais" ${ }^{29}$, ou, em termos mais genéricos, de estados mentais determinados. Assim, lembro-me de que, ainda adolescente, na escola secundária, certo estudante, tendo se aborrecido com um colega negro, não hesitou em afrontar-lhe, em altos brados, com impropérios racistas. Na época, nem sequer ocorreu a alguém que um ato como aquele pudesse ser passível de severa punição. De fato, não o era. Em nossos dias, não é preciso dizer o que aconteceria a um colegial que procedesse dessa maneira. Hoje é sabido que severas punições disciplinares são impostas a colegiais adolescentes por atos racistas incomparavelmente mais "brandos" do que aquele que, no início dos anos de 1970, tive a infelicidade de testemunhar. Receio de que fosse desse tipo de tolerância, isto é, de uma tolerância imposta, antes que autoimposta, ou melhor, autoimposta como o resultado de ter sido previamente imposta (algo análogo ao uso obrigatório do cinto de segurança no Brasil), que Espinosa falava ao se mostrar tão embevecido por sua Amsterdã ${ }^{30}$.

\section{CONCLUSÃO}

Iniciei este artigo mencionando que o pensamento sociológico weberiano é, mais do que qualquer outro, movido pelos desafios de distinguir o velho do novo e de explicar a transição de um para outro. Ao longo do texto, procurei mostrar que Weber enfrentou esses desafios postulando, ainda que involuntariamente, a existência de análogos sociológicos do repouso, de um lado, e de forças que o perturbam a fim de produzir o movimento, de outro. $\mathrm{O}$ análogo sociológico por excelência do repouso é aquilo que Weber chamou de "tradicionalismo", o qual pode se manifestar das mais variadas formas. Examinei duas delas: a mentalidade "quiescente" luterana e o estilo "irracional" do empreendimento judaico. A força que, na perspectiva weberiana, perturba essas formas de tradicionalismo para produzir quer uma mentalidade ativa, quer um estilo racional de empreendimento é, em última análise, a doutrina calvinista da predestinação. Nos marcos do pensamento weberiano, esta última funciona como uma espécie de "plataforma de 
lançamento" a partir da qual se "salta" da "passividade" para a "atividade", do "irracionalismo" para o "racionalismo", enfim, do "velho" para o "novo". Isso posto, argumentei que essa linha de raciocínio levou Weber a enxergar fossos não existentes (entre as mentalidades luterana e calvinista, por exemplo) e a deixar de enxergar fossos existentes (entre a tolerância peculiar aos nossos dias e a de períodos precedentes, por exemplo).

Feita essa recapitulação, cabe agora mencionar que não surpreende que a perspectiva de Weber se tenha enredado em tais dificuldades. Afinal, em vez de primeiro identificar um possível "fosso" para, depois, investigar como ele veio a se formar e como pôde (ou não) ser transposto, se por meio de um salto espetacular ou se de uma forma que não envolve rupturas bruscas, Weber, em primeiro lugar, postula a existência de algo que funcione como uma plataforma de lançamento (por exemplo, a doutrina calvinista da predestinação e a concepção de vocação que lhe é subjacente) para, então, postular a ocorrência do salto que se deu a partir dela e, só então, a existência do fosso cuja transposição necessariamente a requereu. Daí ter postulado, equivocadamente, a existência de um fosso entre as mentalidades luterana e calvinista, de um lado, e entre os estilos judaico e puritano de empreendedorismo, de outro. Quando, por outro lado, não lhe é possível postular de antemão a existência de algo que funcione como a referida plataforma de lançamento, Weber conclui que não há fosso algum a ser transposto e, portanto, que nada de novo se produziu. Daí sua dificuldade em conceder um caráter de novidade à tolerância moderna ou em vislumbrar uma tolerância genuinamente religiosa inteiramente à margem da "transformação da alma do homem" efetuada pelo sectarismo protes$\operatorname{tante}^{31}$. No que se refere a esse ponto, receio de que o exercício tão caracteristicamente weberiano de analisar, em termos típico-ideais, os traços peculiares a um determinado fenômeno (seja o sectarismo ou o que quer que se lhe possa equivaler funcionalmente) que o predispõem a viabilizar algum outro fenômeno (a tolerância religiosa, por exemplo) nem sempre se revela metodologicamente frutífero. No caso em discussão, receio de que suas considerações a respeito das características de uma seita "pura" e do modo como essas características predispõem, em termos típico-ideais, um membro de uma seita a tornar-se um "ferrenho defensor" da liberdade de consciência sejam de todo inúteis quando se trata de compreender o modo como tradições de tolerância religiosa efetivamente se desenvolvem e, mais do que isso, 
como, em nossos próprios dias, a tolerância veio a se converter em um fim em si mesmo.

(Recebido para publicação em maio de 2008)*

(Versão definitiva em maio de 2009)

\section{NOTAS}

1. As citações nos próximos parágrafos cuja fonte não é mencionada foram extraídas da p. 43.

2. Desnecessário lembrar que Weber se valeu da pregação de Benjamin Franklin, tal como aparece em seu livro Advice to a Young Tradesman, de 1748, para extrair a máxima "tempo é dinheiro" e todas as demais listadas anteriormente. Vale também lembrar que a base da noção de que enriquecer é um dever moral é a doutrina calvinista de que o homem trabalha para a glória de Deus, e não em benefício próprio.

3. Ver Graf (1993), especialmente as pp. 40 e 41.

4. Na quinta nota de rodapé do cap. 4 de Weber (1981), podemos ler: "Sobre as diferenças doutrinárias [entre o luteranismo e o calvinismo], o que apresentamos se deve às leituras de Schneckenburger".

5. Ver nota de rodapé 4 e o texto correspondente.

6. Nota de rodapé 37 do cap. 4 (Weber, 1981).

7. Cabe ainda citar Hans de Witte, calvinista da Antuérpia, "o maior industrial, o maior financista, o súdito mais rico da Boêmia, o banqueiro do imperador, da imperatriz, do generalíssimo, da nobreza, do clero, dos próprios jesuítas" (Trevor-Roper, 2007:37).

8. Trata-se de um calvinista que dominou a história econômica francesa de 1639 a 1654 . "Com sua habilidade financeira", conta-nos Trevor-Roper, "manteve o exército da Alsácia leal à França e financiou a política alemã de Mazarino" (2007:34-35).

9. Ver Abrahams (1901:12).

10. Ver, a esse respeito, Rivkin (1967).

11. Na verdade, a expressão "consciência quiescente" é de Schneckenburger, e não de Weber. Como, entretanto, Weber subscreve a posição de Schneckenburger sem qualquer restrição, não constitui uma violência atribuir-lhe o uso de tal expressão.

12. A bem da verdade, há muito mais exemplos. Devo, entretanto, destacar um: o que o próprio Weber chama de o "dualismo universalmente original entre as atitudes morais interna e externa" (2003:359-360), o qual, em sua perspectiva, teria sido espetacu-

* A publicação foi retardada a pedido do autor. 
larmente rompido pelo trabalho missionário de Paulo. Para uma discussão a respeito da pertinência dessa tese, ver Freitas (2007).

13. Ver, por exemplo, o capítulo dedicado ao antissemitismo inglês em Poliakov (1979:178). O autor esclarece que a resistência aos judeus na época de Cromwell vinha justamente dos mercadores tradicionais que com eles competiam, e não de supostos empreendedores "capitalistas burgueses". Ver também Poliakov (1971), especialmente as pp. 36 e 37.

14. A bem da verdade, não era necessário que fosse uma seita protestante. É melhor passar a palavra diretamente a Weber: "Hoje, o tipo de congregação a que alguém pertence é irrelevante. Não importa que se seja maçom, cientista cristão, adventista, quacre, ou qualquer outra coisa. O decisivo é que se seja admitido como membro através de 'votação', depois de um exame e uma comprovação ética no sentido das virtudes que estão a prêmio para o ascetismo, ao mesmo tempo íntimo e voltado para o mundo, do protestantismo, e, daí, para a tradição puritana antiga" (1974:352-353; ênfases no original).

15. Ver Graf (1993:29), especialmente a nota 11.

16. Ver citação da nota 13 deste texto.

17. Graf (1993:29) reproduz trechos inteiros dessa importantíssima carta na nota de rodapé 11 de seu trabalho.

18. Ver especialmente o capítulo XX, parágrafo 246. Ver também Rivkin (1996:272).

19. Essa liberdade religiosa a que Espinosa se refere era recente em Amsterdã, conforme se pode depreender da seguinte passagem de Wilke (2009:119-120): “As autoridades municipais de Amsterdã lembraram aos imigrantes, a partir de 1598, que o culto calvinista era o único permitido na cidade. Em 1603, os primeiros rumores sobre uma organização judaica privada ocasionaram uma investigação criminal; e, em 1612, o conselho municipal ameaçou mandar destruir um edifício em construção, destinado a servir de sinagoga". Nada disso impediu, entretanto, os judeus portugueses de se dotarem de instituições religiosas e comprarem seu próprio cemitério (1614), fundar uma escola (1616), depois uma academia talmúdica (1637) e, em 1639, unificarem-se sob o nome Talmud Torah (Estudo da Lei), à semelhança da sinagoga hispano-portuguesa de Veneza (ibid.:120-121).

20. Ver a nota de rodapé 110 do capítulo 4 de Weber (1981:187).

21. Roger Williams é, na opinião de alguns estudiosos, o principal expoente da tradição puritana de tolerância que se desenvolveu na Inglaterra seiscentista. Notabilizou-se por provocar, em 1644, um "terremoto" no interior da ortodoxia puritana ao apregoar, em seu livro The Bloudy Tenent of Persecution, que, "desde a chegada de Nosso Senhor Jesus Cristo, é a vontade e um mandamento de Deus que as mais pagãs, judaicas, turcas e anticristãs consciências e formas de adoração sejam permitidas a todos os homens e a todas as nações e países" (apud Coffey, 1998:965; tradução minha).

22. Dizem que é mais fácil ver um cisco nos olhos alheios do que nos próprios. Weber viu um cisco nos olhos de seu contemporâneo Ritschl, a quem me referi na segunda seção, e deixou de ver um idêntico em seu próprio. Recordemos que Ritschl, em contraposição a Schneckenburger, concebia um potencial inovador na religião luterana. Ciente de que essa crítica a Schneckenburger atingia seu próprio pensamento, Weber contra-atacou argumentando que a visão de Ritschl era determinada por "seus próprios juízos de valor", pois retratava um luteranismo como, segundo o próprio 


\section{Renan Springer de Freitas}

Ritschl, "deveria ser, e não como foi" (Weber, 1981:165, nota 5 do cap. 4). Ora, não estaria Weber, na citação acima, agindo da mesma maneira? Não estaria idealizando as seitas da mesma forma que, segundo ele próprio, Ritschl teria idealizado o luteranismo? Em conexão com isso, convenhamos que não combina muito com Weber valer-se de uma expressão como "seitas consequentes". Claro está que, vez por outra, Weber esquece seus escrúpulos em relação a juízos de valor - o que não é, diga-se de passagem, necessariamente, uma deficiência.

23. Digo "obscuro" porque jamais vi outra referência a ele a não ser a de Weber. Coffey (1998:964) credita a formação da tradição puritana de tolerância ao trabalho de Thomas Helwys, que, em 1612, fundou a primeira Igreja Batista da Inglaterra.

24. Ver Coffey (1998:984, nota 112).

25. Para uma discussão a respeito das influências sobre a concepção de tolerância de Espinosa, ver Shell (1991:306-335, especialmente as pp. 323 e ss) e Feld (1989).

26. Ver a introdução de Patrick Romanell ao clássico tratado de Locke (1977:9). Um argumento na mesma direção é apresentado por Israel (2000).

27. Pode-se objetar que Weber se limitou a sugerir que há "afinidades eletivas" entre o sectarismo e a tolerância genuinamente religiosa, não sendo, nesse caso, a ocorrência do sectarismo uma condição necessária nem suficiente para a existência da tolerância. A essa objeção gostaria de retorquir que o ato de postular "afinidades eletivas" é um procedimento metodológico inócuo se não nos permite concluir que há, se não uma relação de causalidade, pelo menos alguma tendência à covariação entre os fenômenos ditos "eletivamente afins". Se não for possível, a partir das considerações de Weber a respeito das afinidades existentes entre o sectarismo (ou congregacionalismo) e a tolerância, afirmar que o sectarismo constitui uma via "mais larga" de acesso à tolerância do que as formas não sectárias de religiosidade, então as referidas considerações se tornam inócuas, uma vez que não nos permitem extrair nenhuma implicação.

28. De acordo com Schwartz, havia em Portugal e no mundo luso-hispânico em geral uma tradição de tolerância ou de relativismo religioso que ia além dos limites das próprias concepções de Vieira e que, embora limitada e oprimida pelas políticas do Estado e da Igreja, continuou a existir (2003:34).

29. Recordemo-nos de que a marca, por assim dizer, do "novo homem" de Weber é justamente a "sensação irracional" de haver cumprido devidamente suas tarefas do dia a dia. Na verdade, nada impede que o homem tolerante traga consigo esta marca: que ele tolere simplesmente porque se deve tolerar, mas, na concepção de Espinosa, essa não é uma condição necessária nem suficiente para seu advento. Para Espinosa, o fundamental é a existência de algo como a "autoridade dos magistrados", capaz de proteger até os membros das "seitas mais odiadas".

30. Salvo engano, tanto na concepção de Roger Williams quanto na de Locke, a tolerância era, em larga medida, um atributo autoimposto. O indivíduo tinha de se convencer de que a tolerância era a melhor maneira de servir a Deus. No pensamento de Espinosa, isso não é necessário porque a tolerância é imposta pela autoridade dos magistrados.

31. Ver a nota 27. 


\section{REFERÊNCIAS BIBLIOGRÁFICAS}

ABRAHAMS, Lionel. (1901), "Menasseh Ben Israel's Mission to Oliver Cromwell”. The Jewish Quarterly Review, vol. 14, no 1, pp. 1-25.

COFFEY, John. (1998), “Puritanism and Liberty Revisited: The Case for Toleration in the English Revolution". The Historical Journal, vol. 41, no 4, pp. 961-985.

COHN, Gabriel (org.). (1982), Weber: Coleção Grandes Cientistas Sociais. São Paulo, Ática, vol. 13.

ESPINOSA, Baruch de. (2003), Tratado Teológico-Político. São Paulo, Martins Fontes.

FELD, Edward. (1989), “Spinosa the Jew”. Modern Judaism, vol. 9, no 1, pp. 101-119.

FREITAS, Renan Springer de. (2007), "A Sociologia da Religião como Recapitulação da Teologia Cristã: Weber e as Raízes Proféticas do Racionalismo Ocidental". Revista Brasileira de Ciências Sociais, vol. 22, no 65, pp. 109-125.

GRAF, Wilhelm Friedrich. (1993), "The German Theological Sources and Protestant Church Politics", in H. Lehmann e G. Roth (eds.), Weber's Protestant Ethic: Origins, Evidence, Contexts. Cambridge, Cambridge University Press.

ISRAEL, Jonathan. (2000), "Spinoza, Locke and the Enlightenment Battle for Toleration", in O. Peter Grell e R. Porter (eds.), Toleration in Enlightenment Europe. Cambridge, Cambridge University Press, pp. 102-113.

LEHMANN, Hartmut. (1987), “Ascetic Protestantism and Economic Rationalism: Max Weber Revisited after Two Generations". The Harvard Theological Review, vol. 80, no3, pp. 307-320.

LOCKE, John. (1977), A Letter Concerning Toleration. Indianapolis, Bobs-Merril Educational Publishing.

POLIAKOV, Leon. (1971), O Mito Ariano. São Paulo, Perspectiva.

(1979), História do Anti-Semitismo I: De Cristo aos Judeus da Corte. São Paulo, Perspectiva.

RIVKIN, Ellis. (1967), “Marrano-Jewish Entrepreneurship and the Ottoman Mercantilist Probe in the Sixteenth Century". Cincinnati, OH, Hebrew Union College.

. (1996), “Uma História de Duas Diásporas”, in A. Novinsky e D. Kuperman (orgs.), Ibéria Judaica: Roteiros da Memória. São Paulo, Edusp.

SCHNECKENBURGER, Matthias. [1855], Vergleichende Darstellung des lutherischen und reformierten Lehrbegriffs. Stuttgart, p. 158.

SCHWARTZ, Stuart B. (2003), “The Contexts of Vieira's Toleration of Jews and New Christians". Luzo-Brazilian Review, vol. 40, no 1, pp. 33-44.

SHELL, Marc. (1991), "Marranos (Pigs), or From Coexistence to Toleration”. Critical Inquiry, vol. 17, no 2, pp. 306-335.

TREVOR-ROPER, Hugh. (2007), A Crise do Século XVII: Religião, a Reforma e a Mudança Social. Rio de Janeiro, Topbooks.

WEBER, Max. (1968), Economy and Society. New York, Bedminster Press. 


\section{Renan Springer de Freitas}

. (1974), "As Seitas Protestantes e o Espírito do Capitalismo", in H. Gerth e C. W. Mills (orgs.), Ensaios de Sociologia (3a ed.). Rio de Janeiro, Zahar, pp. 347-370.

. (1981), A Ética Protestante e o Espírito do Capitalismo. São Paulo, Livraria Pioneira. (2003), General Economic History (8a ed.). London, Transactions Publishers.

WILKE, Carsten L. (2009), História dos Judeus Portugueses. Lisboa, Edições 70. 


\section{ABSTRACT \\ Weber and the Advent of the New}

Distinguishing between the old and the new and analyzing the transition from the former to the latter are challenges that acquired unparalleled centrality in Max Weber's sociology of religion. This article examines how Weber dealt with these challenges and the inherent difficulties in his approach. For Weber, the transition from the old to the new necessarily requires something like a "transformation of man's soul" - or a spectacular break with supposedly traditional mindsets. The argument is that this conceptualization led him to see nonexistent breaks (for example, between the Lutheran and Calvinist mentalities) and to fail to perceive important breaks (for example, between present-day tolerance and that of former ages). By way of conclusion, the article contends that there is an analogy between Weber's sociology of religion and Aristotelian physics, and that Weber's view that historically significant transitions require a "transformation of man's soul" can be better understood in light of this analogy.

Key words: sociology of religion; Weberian thought; traditionalism; Protestant sectarianism and religious tolerance

\section{RÉSUMÉ}

\section{Weber et la Venue du Neuf}

Établir la distinction entre le vieux et le neuf et montrer comment on passe de l'un à l'autre sont des enjeux primordiaux dans la sociologie de la religion de Max Weber. Dans cet article, on montre comment Weber les a traités ainsi que ses difficultés à les affronter. Pour Weber, la transition du vieux vers le neuf exige une certaine "transformation de l'âme humaine", ou bien une rupture tranchée avec les types de mentalités tenues pour traditionnelles. On propose que cette conception l'a mené à considérer des ruptures inexistantes (par exemple entre les esprits luthériens et calvinistes) et à ne pas s'apercevoir de ruptures importantes (par exemple, entre la tolérance particulière à nos jours et celle d'époques précédentes). On conclut qu'il y a une analogie entre la sociologie webérienne de la religion et la physique aristotélicienne et que, à la lumière de cette analogie, on peut mieux comprendre ce que Weber veut signifier lorsqu'il affirme que des transitions historiquement significatives demandent une "transformation de l'âme humaine".

Mots-clé: sociologie de la religion; pensée webérienne; traditionalisme; sectarisme protestant; tolérance religieuse 